\title{
INOVASI LIMBAH JAHE MENJADI HAND SANITAZER OLEH KELOMPOK SAHABAT DIFABEL JEPARA DI MASA PANDEMI COVID-19 MELALUI PROGRAM CSR PT PLN UNIT INDUK TANJUNG JATI B
}

\author{
Miftah Arifin, ${ }^{1}$ Sofyan ${ }^{2}$, Wahyu Mahaputra ${ }^{2}$ \\ ${ }^{1}$ Universitas Islam Nahdlatul Ulama Jepara \\ 2 PT. PLN PembangkitTanjungJati B \\ miftah@unisnu.ac.id
}

\begin{abstract}
ABSTRAK
Pemberdayaan merupakan salah satu strategi yang saat ini sedang banyak digunakan dalam pengembangan masyarakat. Pemberdayaan terkait dengan peningkatan pengetahuan dan peningkatan kekuasaan untuk mencapai kondisi berdaya. Kelompok difabel merupakan salah satu kelompok rentan dan sering menjadi subjek pemberdayaan masyarakat. Program pemberdayaan ini mengarah pada penguatan ekonomi kelompok difabel melalui pembuatan sirup herbal dan tanggung jawab lingkungannya melalui pengolahan limbah dari hasil produksi. Metode yang digunakan dalam kegiatan pemberdayaan ini adalah pelatihan dan pendampingan dimana hasilnya dijabarkan dalam deskripsi hasil. Dari hasil pelatihan berdampak pada pembukuan menjadi lebih tertib dan kelompok sudah dapat melaporkan keuangan dengan sederhana. Sedangkan untuk pelatihan pemasaran online berdampak ada peningkatan penjual sebesar $15 \%$ dari sebelumnya. Berkaitan dengan pendampingan yang dihasilkan adalah terjadi peningkatan pendapat telah mendapatkan hasil peningkatan pendapatan Rp. 150.000,- per minggu. Selain pendapatan dalam pendampingan di temukan bahwa terdapat upaya upcycle limbah ampas jahe menjadi hansinitizer dan pembuatan masker ramah difabel tuli dan wicara untuk mempermudah akses komunikasi. Kedua bentuk inovasi produk ini mengakar pada permasalahan pandemi covid-19 dan sebagai bentuk kontribusi inovatif kelompok difabel dalam pencegahan covid melalui pemanfaatan limbah.
\end{abstract}

Kata Kunci : Inovasi, Limbah, Difabel, Pemberdayaan, CSR

\section{ABSTRACT}

Empowerment is one strategy that is currently being widely used in community development. Empowerment is related to increasing knowledge and increasing power to achieve a state of empowerment. The diffable group is one of the vulnerable groups and is often the subject of community empowerment. This empowerment program aims to strengthen the economy of the diffable groups through the manufacture of herbal syrups and environmental responsibility through processing waste from production. The method used in this empowerment activity is training and mentoring where the results are described in the results description. From the training results, it has an impact on bookkeeping to be more orderly and groups are able to report finances simply. 
Meanwhile, online marketing training resulted in an increase in sellers by $15 \%$ from the previous one. Related to the assistance generated is an increase in opinion that has resulted in an increase in income of Rp. 150,000, - per week. In addition to income in assistance, it was found that there were efforts to upcycle ginger waste to become sanitizers and make masks for the deaf and speech disabled to facilitate communication access. These two forms of product innovation are rooted in the problem of the Covid-19 pandemic and as a form of innovative contribution from the diffable group in preventing Covid through the use of waste.

Keywords : Inovation, Waste, Difabel, Empowerment, CSR 


\section{PENDAHULUAN}

Negara Republik Indonesia adalah negara yang berdasarkan Pancasila dan Undang-Undang Dasar Negara Republik Indonesia Tahun 1945 yang menghormati dan menjunjung tinggi harkat dan martabat manusia sehingga perlindungan dan kemajuan hak asasi manusia terhadap kelompok rentan khususnya penyandang disabilitas harus diperhatikan. Komitmen negara dalam perlindungan hak asasi manusia, termasuk pada penyandang disabilitas telah ditegaskan dalam perundangan.

Disabilitas adalah sebuah konsep yang menjelaskan hasil dari interaksi antara individu-individu yang mempunyai keterbatasan fisik atau mental/intelektual dengan sikap dan lingkungan yang menjadi penghambat kemampuan mereka berpartisipasi di masyarakat secara penuh dan sama dengan orang-orang lainnya. Pengakuan ini secara tidak langsung menyatakan bahwa persoalan hambatan berpartisipasi harus menjadi tanggung jawab masyarakat dan Negara. Sikap masyarakat dan kebijakan pemerintah yang mengakomodasi prinsip Hak Asasi Manusia (HAM) non-diskriminasi, kesetaraan serta kesempatan yang sama dan mengakui adanya keterbatasan yang dapat diatasi jika diupayakan aksesibilitas fisik dan non-fisik merupakan factor penting dalam mengatasi kondisi yang disebut "disabilitas".

Anggapan masyarakat yang terbangun terkait Stigma sosial dan paradigm difabel yang harus mulai dirubah. Stigma kepada difabel dapat beroperasi pada dua level, yaitu eksplisit dan implisit [1]. Difabel selalu dipandang sebelah mata. Para difabel dalam satu hal tidak dapat disamakan dengan orang yang diberi kesehatan fisik. Namun hal ini bukan berarti mereka memiliki ketidakmampuan untuk mengambil bagian dalam kehidupan masyarakat pada tingkatan yang sama dengan orang yang tidak termasuk dalam golongan difabel. Untuk mewujudkan hal itu, difabel memerlukan wadah untuk membangun dan mengembangkan kemampuan atau kreatifitas yang dimiliki. 
Jumlah dan jenis penyandang disabilitas di Kabupaten Jepara tidak dapat terdeteksi secara valid. Tahun 2019, jumlah penyandang disabilitas yang tercatat oleh Dinas Sosial sebanyak $0,65 \%$ dari total penduduk Kabupaten Jepara. Angka tersebut terbagi hanya dalam enam jenis penyandang disabilitas. Dari enam jenis tersebut terdapat 8 paguyuban bagi penyandang disabilitas. Tujuan dari paguyuban tersebut salah satunya adalah untuk menampung aspirasi dari beberapa penyandang disabilitas tersebut. Kendala yang di hadapi oleh paguyuban tersebut adalah tentang pendataan anggota pihak keluarga yang membatasi bagi keluarganya yang menyadang disabilitas karena perasaan malu karena masih adanya anggapan bahwa kondisi difabel merupakan aib. Kendala lainya berkaitan dengan aksesibiltas bagi tuna netra perlu pendampingan dalam kegiatan jarak jauh, serta factor kemampuan ekonomi yang kurang.

Kelompok Sahabat Difabel Jepara yang sering dikenal dengan "Sadifa" Jepara merupakan salah satu paguyuban difabel yang paling eksis dalam melakukan peningkatan pemberdayaan ekonomi di kabupaten Jepara. Kelompok "Sadifa" Jepara terbentuk tahun 2012 dan sudah mendapatkan surat pengesahan dari Kementrian Hukum dan HAM sebagai perkumpulan pada tahun 2017 yang memiliki jumlah anggota kurang lebih 50 anggota. Kelompok "Sadifa" Jepara memiliki usaha bidang produksi pengolahan rempah-rempah berupa pembuatan sirup jahe, jahe instan, sirup temulawak dan jenis minuman yang berbahan dasar rempah-rempah atau empon-empon. Menurut guru besar biologi molekuler dari Universitas Airlangga, Chaerul Anwar Nidom dalam health detik.com (https://health.detik.com/berita-detikhealth/d-4959119/apa-sajatanaman-herbal-yang-dapat-mencegah-covid-19), mengatakan bahwa tanaman herbal asli Indonesia yang berupa empon-empon dapat mencegah virus corona. Bidang usaha yang dikembangkan oleh Kelompok "Sadifa" Jepara dapat membantu masyarakat jepara pada khususnya sebai pencagahan berkembangnya virus corona. Dimana kabupaten jepara pada awal tahun 2020 berdasarkan sumber data dari 
Gugus tugas percepatan penanganan covid-19 kabupaten mengalami peningkatan setiap bulanya. Dimana Orang Dalam Pemantauan (ODP) sebanyak 989 orang, Pasien Dalam Pengawasan (PDP) sebanyak 173 orang, Kasus terkonfirmasi Covid-19 sebanyak 376 kasus.

Dengan banyaknya kasus covid-19 di Jepara maka Kelompok "Sadifa" Jepara melakukan terobosan dengan melengkapi legalitas produk tersebut dengan ijin PIRT dari dinas kesahatan kabupaten Jepara. Selain sirup yang berbahan baku dari empon-empon, Kelompok "Sadifa" Jepara juga mencoba membuat trobosan dimasa pedemi virus corana ini dengan mengolah limbah empon-empon dimanfaatkan sebagai hand sanitizer serta membuat masker untuk difabel yang berbahan baku dari kain limbah dari pabrik garment yang ada di sekitarJepara.

Dengan melihat potensi dan peluang dari usaha Kelompok "Sadifa" Jepara, maka PT. PLN Bembangkit Tanjung Jati B melalui dana Corporate Social Responsbility (CSR) melakukan pendampingan secara intens untuk pengembangan lebih lanjut dari usaha Kelompok "Sadifa" Jepara. Kegiatan pendampingan terhadap kelompok tersebut mendasarkan pada Peraturan Menteri BUMN Nomor: Per-02/MBU/7/2017 tanggal 05 Juli 2017 tentang Perubahan Kedua atas Peraturan Menteri Badan Usaha Milik Negara Nomor Per-09/Mbu/07/2015 tentang Program Kemitraan dan Program Bina Lingkungan Badan Usaha Milik Negara. Dari peraturan menteri BUMN tersebut berisi dua program yang akan dilakukan yaitu Program Kemitraan dan Program Bina Lingkungan. Pengertian tentang program kemitraan dapat dijelaskan lebih lanjut dalam ketentuan pasal 1 poin 6 disebutkan bahwa Program Kemitraan BUMN yang selanjutnya disebut Program Kemitraan adalah program untuk meningkatkan kemampuan usaha kecil agar menja ditangguh dan mandiri. Sedangkan untuk Program Bina Lingkungan penjelasanya ada dalam ketentuan pasal 7 point7 yang isinya adalah Program Bina Lingkungan yang selanjutnya disebut Program BL adalah program pemberdayaan kondisi social masyarakat oleh BUMN. 
Menurut Andina [2] memberikan sebuah konsep tentang pemberdayaan, dimana pemberdayaan bukan hanya merupakan hasil atau capaian akan tetapi pemberdayaan merupakan sebuah proses dan tujuan. Pemberdayaan dikatakan sebuah proses, diartikan serangkaian kegiatan untuk memperkuat kekuasaan atau keberdayaan kelompok lemah dalam masyarakat, termasuk individu-individu yang mengalami masalah kemiskinan. Sedangkan dikatakan sebagai tujuan, artinya pemberdayaan menunjukkan pada keadaan atau hasil yang ingin dicapai oleh sebuah perubahan sosial; yaitu masyarakat yang berdaya, memiliki kekuasaan atau memiliki pengetahuan dan kemampuan dalam memenuhi kebutuhan hidup baik yang bersifat fisik, ekonomi, maupun social seperti memiliki kepercayaan diri, mampu menyampaikan aspirasi, memiliki mata pencaharian, berpartisipasi dalam kegiatan social serta mandiri dalam melaksanakan tugas- tugas kehidupannya.

Pemberdayaan menurut Payne (1997) dalam Adi (2003) [3] adalah: "membantu klien memperoleh daya untuk mengambil keputusan dan menentukan tindakan yang akan dilakukan yang terkait diri mereka, termasuk mengurangi efek hambatan pribadi dan social dalam melakukan tindakan. Hal ini dilakukan melalui peningkatan kemampuan dengan rasa percaya diri untuk membentuk masa depan sesuai dengan keinginan mereka".

Menurut Tesoriero (2008: 558) sedikitnya ada tiga peran dan keterampilan dalam melakukan pemberdayaan, diantaranya: [4]

1) Peran memfasilitasi adalah yang berkaitan dengan stimulasi dan penunjang pemberdayaan masyarakat. Dimana terdapat beberapa kategori peran memfasilitasi, antara lain: semangat social; mediasi dan negosiasi; dukungan; membangun consensus; fasilitasi kelompok, pemanfaatan berbagai keterampilan dan sumberdaya, mengorganisasi, dan komunikasi pribadi.

2) Peran mendidik dimana berperan aktif sebagai agen yang memberikan masukan positif dan direktif berdasarkan pengetahuan 
dan pengalamannya. Dimana terdapat beberapa kategori peran, diantaranya: peningkatan kesadaran; memberikan informasi mengenai berbagai sumber eksternal; pelatihan;

3) Peran representasi digunakan untuk menunjukkan berbagai peran dalam masyarakat untuk berinteraksi dengan pihak luar demi kepentingan masyarakat. Beberapa kategori peran tersebut antara lain: memperoleh berbagai sumberdaya dalam membantu sebuah masyarakat untuk memperoleh berbagai sumber informasi, ketrampilan dan keahlian yang dibutuhkan agar mampu mendirikan berbagai struktur sendiri dan menemukan tujuan sendiri; advokasi; menggunakan media; humas; jaringankerja dan menyampaikan berbagai ide atas pengetahuan dan pengalaman yang didapat.

Kendala yang dihadapi oleh Kelompok "Sadifa" Jepara dalam pengembangan usahanya adalah berkaitan dengan manajemen usaha, manajemen produksi dan Pemasaran produk yang telah di hasilkan dibutuhkan mitra untuk pengembangan usaha dari kelompok "Sadifa" Jepara. Berkenaan dengan keseriusan dari Kelompok "Sadifa" Jepara dalam pengembangan usahanya, PT. PLN Pembangkit Tanjung Jati B salah satu BUMN mencoba melakukan pendampingan dan pemberdayaan terkait dengan usaha dari Kelompok "Sadifa" Jepara.

\section{METODE PELAKSANAAN}

Berdasarkan permasalahan yang dihadapi oleh kelompok "Sadifa" Jepara, program pendampingan yang di lakukan oleh PT.PLN Pembangkit Tanjung Jati B melalui dana CSR-nya dilakukan melalui metode pelaksanaan sebagai berikut: Metode pelaksanaan pertama adalah metode konsultasi ditujukan untuk menggali akar permasalahan, menentukan solusi dari aspek pasar dan pemasaran, aspek produksi / operasi, aspek manajemen dan organisasi, aspek SDM, aspek keuangan dan aspek permodalan, usaha Kelompok "Sadifa" Jepara, harapannya adalah kelompok tersebut dapat mengetahui, memahami dan dapat 
menentukan solusi permasalahan. Termasuk dalam tahap ini menggali informasi untuk menentukan jenis media promosi apa yang efektif dan menggali system manajemen usaha yang tepat. Dalam metode konsultasi menggunakan pendekatan Input - Proses - Output

Metode pendekatan kedua adalah dengan metode pelatihan tujuannya adalah memberikan keahlian kepada Kelompok "Sadifa" Jepara aspek-aspek aktivitas usaha yang belum terpecahkan solusinya pada metode pendekatan konsultasi. Dalam pendekatan ini dilaksanakan setelah ditentukan masalah yang membutuhkan layanan tindak lanjut pelatihan dari hasil konsultasi terhadap semua aspek-aspek aktivitas usaha Kelompok "Sadifa" Jepara, Metode yang digunakan dalam metode pelatihan adalah menggunakan pendekatan pemecahan masalah (problem solving) praktis sesuai hasil konsultasi yang perlu tindak lanjut pelatihan,.

Metode pendekatan yang ketiga adalah metode pendampingan ditujukan agar Kelompok "Sadifa" Jepara menerapkan hasil konsultasi dan pelatihan dimana tim melakukan evaluasi serta pendampingan dalam melaksanakan semua aspek aktivitas usaha sehingga mitra mampu menentukan dan memutuskan strategi atau penanganan permasalahan yang dihadapi. Selain pendampingan untuk meningkatkan proses produksi dan menjaga kualitas produk yang dihasilkan oleh Kelompok "Sadifa" Jepara, PT. PLN Pembangkit Tanjung Jati B juga memberikan beberapa fasilitasi peralatan yang berupa dibangunkanya rumah produksi, peralatan berupa freezer, mesin parut, dan lain-lain.

\section{HASIL DAN PEMBAHASAN}

Kelompok "Sadifa" Jepara memiliki kemampuan untuk memproduksi sirup rempah-rempah berasal dari otodidak dari salah satu anggota kelompok, yang kemudian didukung oleh anggota kelompok yang lain. Pendampingan yang di lakukan oleh PT. PLN Pembangkit Tanjung Jati B kepada Kelompok "Sadifa" Jepara dimulai pada tahun 2018, 
dimana diawali dengan penggalian informasi permasalahan yang dihadapi oleh kelompok "Sadifa" Jepara. Dari penggalian masalah tersebut di dapatkan beberapa akar masalah berkaita dengan usaha kelompok tersebut antara lain: kemampuan Sumber Daya Manusia, keterbatasan modal usaha, sarana dan prasarana yang dimiliki kelompok tersebut.

Menindaklanjuti akar masalah pertama yang dihadapi oleh Kelompok "Sadifa" Jepara berkaitan dengan kemampuan sumberdaya manusia, PT. PLN Bembangkit TanjungJati B melakukan beberapa pelatihan untuk meningkatkan kemampuan anggota Kelompok "Sadifa" Jepara. Pelatihan yang dilaksanakan adalah pelatihan berkenaan dengan manajemen usaha, pelatihan packaging, dan pemasaran online.

Pelatihan manajemen usaha menitikberatkan pada pengelolaan keuangan diimana kebayakan pelaku usaha yang skupnya masih mikro dan kecil biasanya lemah pada pengelolaan keuangan. Berkaitan dengan manajemen keuangan, ada empat aspek yang perlu diperhatikan yaitu sumber pendanaan, perencanaan keuangan, manajemen pemasukan dan pengeluaran. Pengembangan manajemen keuangan diarahkan agar kelompok "Sadifa" jepara memiliki system pengelolan keuangan yang standard sehingga bisa dijadikan dasar pendanaan kepada pihak lain. Kelompok "Sadifa" jepara sumber pendanaanya berasal dari iuran anggota dan bantuan dari pihak lain. Selama kegiatan pendampingan yang dilakukan oleh PT. PLN Bembangkit Tanjung Jati B, anggota kelompok dilatih untuk dapat meningkatkan kemampuan manajemen keuangan dengan tujuan agar manajemen keuangan yang baik dapat menunjang produktivitas usaha. Target dari pelatihan ini mampu membuat pembukuan sederhana mampu membuat catatan transaksi penjualan dan pembelian sirup, masker dan produk lain yang dihasilkan oleh Kelompok "Sadifa" jepara, dan pembuatan laporan keuangan standar. Adapun hasil analisis kegiatan pelatihan dan pendampingan manajemen keuangan adalah sebagai berikut: Kelompok "Sadifa" jepara sudah memiliki pembukuan keuangan dan administrasi kelompok yang lengkap dan 
tertib sehingga dalam pengambilan kebijakan pengembangan Kelompok "Sadifa" jepara dapat dilakukuan dengan tepat.

Pelatihan yang kedua adalah pelatihan pemasaran online, Persoalan pemasaran merupakan hal utama dalam suatu usaha yakni di sisi marketing atau pemasaran, marketing merupakan ujung tombak dari suatu usaha untuk mampu berkembang, ini karena marketing adalah media yang akan menghubungkan produsen ke konsumen. Kelompok "Sadifa" jepara masih mengandalkan media konfensional dalam system pemasaran, sehingga tim pendamping dari PT. PLN Pembangkit tanjung Jati B mencoba melakukan pelatihan pemasaran Offline dan Online. Untuk permasalahan pemasaran, tim pendamping dari PT. PLN Pembangkit tanjung Jati B mengembangkan cara pemasaran yang telah dilakukan selama ini yaitu dengan Konsinyasi (menitipkan Barang di Toko) dan Direct Selling (melakukan penjualan langsung), dari hasil analisis permasalahan yang dilakukan oleh tim pendamping dari PT. PLN Pembangkit tanjung Jati B dari kedua model pemasaran yang telah dilakukan oleh Kelompok "Sadifa" jepara adalah konsumen masih belum mengenal dan yakin dengan produk yang dihasilkan dari kedua kelompok usaha bersama tersebut karena tampilan kemasan yang masih sangat sederhana. Sehingga untuk memperbaiki kemasan (packaging) dilakukan pelatihan tentang kemasan (packaging) sebagai penunjang dari pemasaran, agar produk yang dihasilkan memiliki tampilan yang menarik.

Kelompok "Sadifa" jepara diberikan pelatihan tentang pemasaran online dengan media social media yaitu facebok, istagram, twiters. Pelatihan tersebut materinya melingkupi Teknik meningkatkan followers sehingga dapat dibaca oleh konsumen. Dan bagaimana menampilkan produk di social media dengan baik dan menarik. Hasil dari pelatihan ini ada peningkatan penjualan sebesar $15 \%$ produk yang telah dipasarkan.

Berkaitan dengan akar masalah yang kedua yaitu tentang keterbatasan modal usaha, PT. PLN Pembangkit Tanjung Jati B tidak memberikan modal usaha berupa pemberian sarana dan prasarana 
berupa tempat produksi dan beberapa alat produksi, tujuan dari pemberian alat dan tempat produksi adalah untuk meningkatkan produktifitas usaha.

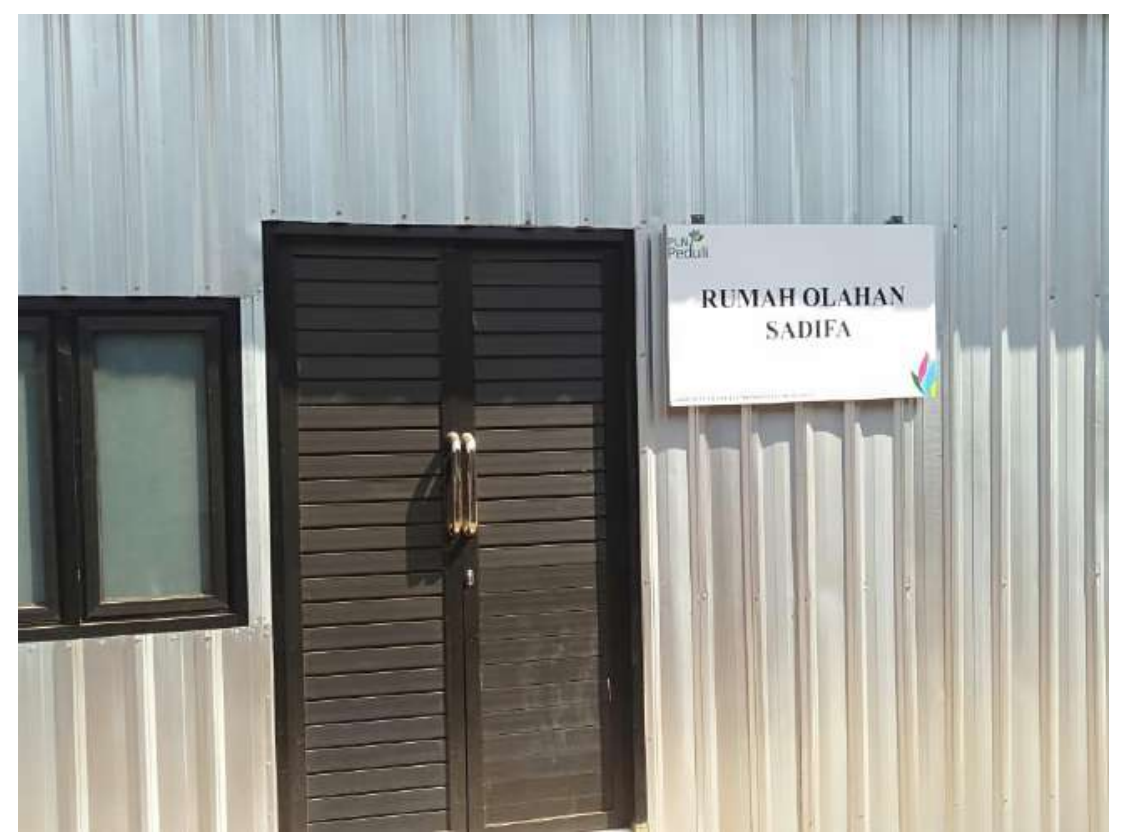

Gambar.1

Rumah Olahan Bantuan PT. PLN Pembangkit Tanjung Jati B

Dari bantuan rumah olahan tersebut Kelompok "Sadifa" jepara memiliki tempat pengolahan produk dengan baik sesuai dengan standard dari departemen kesehatan. Dari bantuan tersebut juga produk Kelompok "Sadifa" jepara sudah mendapatkan surat P-IRT dari dinas Kesehatan Kabupaten Jepara. Sedangkan bantuan alat pemarut rempah-rempah, dapat menghasilkan efisien waktu 5 kali lipat hasil parutan rempahrempah bila dibandingkan dengan menggunakan manual. Sehingga akan memnghasilkan penghematan biaya produksi kalau pekerjaan tersebut di lakukan oleh pekerja pengupas dan pemarut rempah-rempah secara manual.

Dari bantuan peralatan dari PT. PLN Pembangkit Tanjung Jati B setiap satu minggu Kelompok "Sadifa" jepara dapat memproduksi sirup jahe, sirup temulawak sebayak 100 botol, bila dibandingkan sebelum 
mendapatkan bantuan alat Kelompok "Sadifa" Jepara hanya dapat memproduksi sirup hanya 25 botol per minggu dengan biaya produksi setiap botol Rp. 25.000,- dengan harga jual Rp.35.000. Adapun biaya produksi setiap botol sirup jahe setelah mendapatkan bantuan alat kurang lebih Rp. 20.000,- sedangkan harga jual sirup tersebut Rp. 35.000,-. Ada selisih biaya produksi sebesar Rp. 5.000 setiap botol setelah mendapatkan bantuan peralatan.

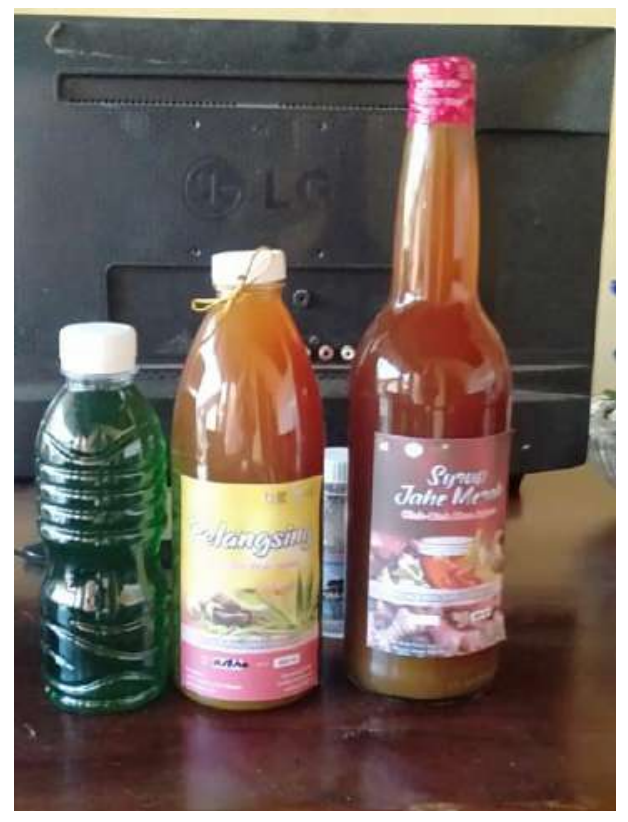

Gambar.2

ProdukKelompok"Sadifa"Jepara

Berdasarkan hasil produksi diatas maka pendapatan dari Kelompok "Sadifa" Jepara selama satu minggu dengan harga per sirup Rp. 35.000,dan biaya produksi Rp. 20.000,- maka ada selisih dan itu menjadi keuntungan bagi Kelompok "Sadifa" Jepara sebesar 15 setiap botol, dan itu kalau dikalikan 100 botol setiap minggu maka Kelompok "Sadifa" Jepara akan mendapatkan keuntungan sebesar Rp. 150.000, setiap minggu. Jumlah produksi yang dihasilkan oleh Kelompok "Sadifa" Jepara dari tinjauan tim pendamping dari PT. PLN Pembangkit Tanjung 
Jati B masih bisa ditingkatkan ketika bahan baku tersebut bisa di tingkatkan.

Inovasi yang sekarang dikembangkan oleh Kelompok "Sadifa" Jepara adalah melakukan daur ulang dari limbah bahan baku sirup yang akan digunakan bahan baku pembuatan Hand Sanitazer. Produksi inovasi tersebut masih dalam uji coba dan selalu didampingi oleh tim pendamping dari PT. PLN Pembangkit Tanjung Jati B, harapanya akan mendapatkan hasil yang maksimal sehingga dapat dipasarkan di masyarakat.

\section{SIMPULAN DAN SARAN}

\section{Simpulan}

1. Kegiatan pelatihan manajemen keuangan yang dilakukan oleh tim PT. PLN Pembangkit Tanjung Jati B berdampak pada kelompok "Sadifa" Jepara sudah memiliki pembukuan keuangan yang tertib bahkan sudah bisa membuat laporan keuangan yang sederhana.

2. Kegiatan pelatihan pemasaran secara online berdampak pada meningkatkan penjualan produk sebesar $15 \%$ dari sebelumnya.

3. Pelaksanaan pendampingan oleh tim PT. PLN Pembangkit Tanjung Jati B kepada Kelompok "Sadifa" Jepara setidaknya telah mendapatkan hasil peningkatan pendapatan Rp. 150.000,- per minggu.

\section{Saran}

Kegiatan pendampingan yang dilakukan oleh tim PT. PLN Pembangkit Tanjung Jati B kepada Kelompok "Sadifa" Jepara harus dilanjutkan secara tuntas, karena masih banyak inovasi dari Kelompok "Sadifa" Jepara yang belum selesai tuntas, misalnya pembuatan Hand Sanitazer yang berbahan baku dari limbah bahan baku sirup yang masih terus dikawal sehingga dapat digunakan dan dapat dipasarkan. 


\section{DAFTAR PUSTAKA}

1. Cleoputri Yusainy dkk, 2016 , "Stop Ableism: Reduksi Stigma kepada Penyandang Disabilitas melalui Intervensi Bias Implisit", Jurnal Psikologi, Vol. 43 No. 1

2. Andina, E. P. M., (dkk). 2014. Pembadanan (Embodying) Kebijakan Berbasis Kapasitas dalam Pemberdayaan Difabel Untuk Penanggulangan Kemiskinan. Jurnal Dinamika Hukum.

3. Adi, Isbandi Rukminto. 2003. Pemberdayaan Pengembangan Masyarakat dan Intervensi Komunitas. Jakarta: Lembaga Penerbit Fakultas Ekonomi Universitas Indonesia

4. Tesoriero, Jim \& Ife Frank. 2008. Community Development. Yogyakarta: Pustaka Pelajar 